\title{
Features of the growth and development of young pigs of various breeding
}

\author{
Olga Tretyakova ${ }^{1}$, Anna Degtyar $^{1}$, Alexander Avdeyev ${ }^{1}$, Dmitry Ovchinnikov ${ }^{1 *}$, and Irina \\ Morozyuk $^{1}$ \\ ${ }^{1}$ Don State Agrarian University, Persianovskiy, 24, Krivoshlykova st., 346493, Rostov region, Russia
}

\begin{abstract}
The indicators of growth and development, fattening and meat qualities of pigs of the breeding center "Lozovoe" CJSC "PlemzavodYubileyny" of the Tyumen region were evaluated. The indicators that characterize the growth and development of young animals were taken into account: live weight, age, average daily growth. When the live weight of $100 \mathrm{~kg}$ was reached, an ultrasound device was used to evaluate the thickness of bacon, the depth of muscles and the yield of lean meat, which are in the database of breeding records for 2011-2020. To characterize the meat qualities, 1144 Landrace piglets were slaughtered, 275 - large white breed, 129 - Pietren breed, 339 hybrids (LxKB), 159 hybrids (LxD), 460 hybrids obtained from boars of foreign selection. A comparative analysis of commercial hybrids of various variants of crossing pigs of domestic and foreign selection is carried out. Processing of the research results was carried out in the laboratory of Molecular diagnostics and Biotechnology of the Don State Agrarian University. The influence of the breed is established.
\end{abstract}

\section{Introduction}

Currently, a large number of imported livestock from various countries of Europe and North America are imported to the Russian Federation at pig breeding complexes, the analysis of their adaptation and use is of great importance for the development of regional hybridization systems. [3,4,5]

In this regard, one of the important areas of research is the study of the growth, development and formation of meat qualities of domestic and foreign genetic material and the possibility of its further use.

Scientific research by many authors and the production practice of the complexes show that improving the quality of meat largely depends on the rational use of the genetic potential of pig breeds. In this regard, the study of the quality of the imported livestock in the conditions of domestic complexes is of particular importance. Search for the possibility of using genetic resources to create competitive young animals of their own production. $[1,2,3,4,5]$

The studies were carried out in accordance with the directions of scientific research of the Don State Agrarian University of the Federal State Educational Institution of Higher

\footnotetext{
*Corresponding author: ovchinnikoff.dmitrij2014@yandex.ru
} 
Education: "Increasing the genetic potential of farm animals, the effectiveness of its use", "Determining the effectiveness of using various domestic and imported breeds, types and lines in industrial crossing and hybridization in the breeding system pigs".

\section{Purpose and objectives of research}

The main purpose of the research was to study the indicators of growth and development, fattening and meat qualities of purebred and hybrid pigs of imported and domestic selection.

To achieve this goal, the following tasks were identified:

- Study the growth and development of purebred and hybrid young stock.

- Identify the most effective breed combinations for obtaining commercial hybrids.

\section{Material and research technique}

The research was carried out in the breeding center "Lozovoe" CJSC "PlemzavodYubileiny" of the Ishim district of the Tyumen region and the laboratory of molecular diagnostics and biotechnology of the Don State Agrarian University. Zootechnical information was analyzed using the pedigree registration database for 2011-2020 (ACC program, Selikom company, Ryazan). MS Excel spreadsheet was used for data processing.

\section{Research results}

At the first stage of the research, the study of the growth and development of purebred and hybrid young animals was carried out. Analyzed 1766 heads of pigs of all breeds, growth and development indicators are shown in table 1.

Table 1. Indicators of growth and development of purebred gilts.

\begin{tabular}{|c|c|c|c|c|c|c|}
\hline breed & $\begin{array}{c}\text { number, } \\
\text { heads }\end{array}$ & $\begin{array}{c}\text { early } \\
\text { maturity } \\
\text { days }\end{array}$ & $\begin{array}{c}\text { body } \\
\text { length, } \\
\mathbf{c m}\end{array}$ & $\begin{array}{c}\text { fat } \\
\text { thickness } \\
\text { mm }\end{array}$ & $\begin{array}{c}\text { age of the } \\
\text { first } \\
\text { muscle } \\
\text { depth, mm } \\
\text { inseminatio } \\
\text { n, } \\
\text { days }\end{array}$ \\
\hline large white & 275 & 166 & 117 & 13 & 56 & 263 \\
\hline duroc & 257 & 149 & 114 & 12 & 54 & 245 \\
\hline pietrain & 90 & 173 & 114 & 11 & 64 & 257 \\
\hline landrace & 1144 & 147 & 119 & 10 & 54 & 241 \\
\hline all breeds & 1766 & 151 & 118 & 11 & 55 & 243 \\
\hline
\end{tabular}

There is a decrease in the age at which live weight is reached in four years by breeds: Pietrain for 28 days, Large White for 20 days, Duroc for 7 days, Landrace for 2 days. Considering the changes in body length in gilts, we see that this indicator changed upward in breeds: pietrain by $1 \mathrm{~cm}$, landrace by $0.3 \mathrm{~cm}$, and in the Duroc breed it decreased by 5 $\mathrm{cm} .8 \mathrm{~mm}$, in the Duroc breed by $5 \mathrm{~mm}$.

663 boars of all breeds were evaluated by the method of control rearing. The results of the assessment of boars are shown in Table 2 . 
Table 2. Evaluation of boars upon reaching a live weight of $100 \mathrm{~kg}$.

\begin{tabular}{|c|c|c|c|c|c|}
\hline Breeds & $\begin{array}{c}\text { Early } \\
\text { maturity, } \\
\text { days }\end{array}$ & $\begin{array}{c}\text { Lard } \\
\text { thickness, } \\
\text { mm }\end{array}$ & $\begin{array}{c}\text { Average daily } \\
\text { gain, }\end{array}$ & $\begin{array}{c}\text { Feed costs, } \\
\text { feed items }\end{array}$ & $\begin{array}{c}\text { Muscle } \\
\text { depth, mm }\end{array}$ \\
\hline Large white & 147.5 & 12.6 & 1016 & 2.8 & 51 \\
\hline Duroc & 137 & 11 & 1062 & 2.8 & 51 \\
\hline Landrace & 133 & 11 & 1144 & 2.7 & 49 \\
\hline Pietrain & 145 & 11.5 & 1008 & 2.8 & 58 \\
\hline
\end{tabular}

The smallest age to reach a live weight of $100 \mathrm{~kg}$ is noted in Landrace boars - 133 days and Duroc - 137 days. It should be noted that the average daily gain in boars exceeds $1 \mathrm{~kg}$.

During the study period, 159 heads of two-breed hybrids of the Yubileiny selection were analyzed. The results of statistical processing are shown in Table 3.

Table 3. Indicators of slaughter qualities of hybrid pigs LxD.

\begin{tabular}{|l|c|c|c|c|c|}
\hline \multicolumn{1}{|c|}{ Indicators } & $\begin{array}{c}\text { Fat (6-7 thoracic } \\
\text { vertebra). } \mathbf{~ m m}\end{array}$ & $\begin{array}{c}\text { Fat (10-11 } \\
\text { rib). mm }\end{array}$ & $\begin{array}{c}\text { Muscle depth. } \\
\text { mm }\end{array}$ & Weight. kg & $\begin{array}{c}\text { Output. } \\
\text { \%o }\end{array}$ \\
\hline Average & 22.78 & 13.26 & 61.18 & 79.02 & 54.97 \\
\hline Standard error & 0.42 & 0.28 & 0.68 & 0.73 & 0.18 \\
\hline Median & 23 & 12.9 & 61.6 & 78.8 & 55.2 \\
\hline Fashion & 29 & 10.7 & 61.4 & 63.3 & 55.2 \\
\hline Standard deviation & 5.35 & 3.47 & 8.52 & 9.23 & 2.27 \\
\hline Excess & -0.16 & -0.22 & 0.49 & -0.02 & -0.45 \\
\hline Asymmetry & 0.15 & 0.41 & -0.54 & -0.15 & -0.47 \\
\hline Interval & 30 & 16.6 & 49 & 47.6 & 10.1 \\
\hline Minimum & 10 & 5.9 & 33.1 & 54.9 & 49.4 \\
\hline Maximum & 40 & 22.5 & 82.1 & 102.5 & 59.5 \\
\hline $\begin{array}{l}\text { Reliability level } \\
\text { (95.0\%) }\end{array}$ & 0.84 & 0.54 & 1.33 & 1.45 & 0.36 \\
\hline
\end{tabular}

The average values for the group of LxD hybrids were: the thickness of the fat over 6-7 thoracic vertebrae was $22.78 \mathrm{~mm}$, the thickness of the fat at the level of 10-11 ribs was $13.26 \mathrm{~mm}$, the depth of the muscle was $61.18 \mathrm{~mm}$, the yield was $54.95 \%$.

A high negative degree of connection between fat thickness and meat yield was found 0.32 and -0.96 . The degree of connection between the depth of the muscle and the output was 0.26; at high values of the depth of the muscle in individual individuals and purposeful work on the selection and selection of pairs, it can be effective.

461 heads of hybrids obtained from terminal boars of foreign selection were analyzed, the statistical analysis is given in Table 4.

Table 4. Indicators of slaughter qualities of hybrid gilts L x Terminal boars.

\begin{tabular}{|l|c|c|c|c|c|}
\hline \multicolumn{1}{|c|}{ Indicators } & $\begin{array}{c}\text { Fat (6-7 } \\
\text { thoracic } \\
\text { vertebra). } \mathbf{~ m m}\end{array}$ & $\begin{array}{c}\text { Fat (10-11 rib). } \\
\mathbf{~ m m}\end{array}$ & $\begin{array}{c}\text { Muscle depth. } \\
\mathbf{m m}\end{array}$ & Weight. kg & Output. \% \\
\hline Average & 21.40 & 11.75 & 61.91 & 73.47 & 55.67 \\
\hline Standard error & 0.24 & 0.19 & 0.38 & 0.43 & 0.12 \\
\hline Median & 21 & 10.9 & 62.2 & 74.2 & 56.3 \\
\hline Fashion & 19 & 8.4 & 61.7 & 72.3 & 57.9 \\
\hline Standard deviation & 5.12 & 3.99 & 8.07 & 9.30 & 2.60 \\
\hline Excess & -0.23 & 1.41 & 0.06 & 4.91 & 1.43 \\
\hline Asymmetry & 0.17 & 1.05 & -0.37 & -0.88 & -1.13 \\
\hline Interval & 29 & 24.3 & 44.3 & 90.3 & 16.3 \\
\hline Minimum & 7 & 5.9 & 36.5 & 8.1 & 44 \\
\hline Maximum & 36 & 30.2 & 80.8 & 98.4 & 60.3 \\
\hline Reliability level (95.0\%) & 0.47 & 0.37 & 0.74 & 0.85 & 0.24 \\
\hline
\end{tabular}


Correlation coefficients between fat thickness and meat yield have a high negative relationship -0.54, -0.97 . The relationship between muscle depth and meat yield was 0.32 .

The end product of the pig-breeding complex is commercial hybrids obtained from a hybrid pig (Large White $\mathrm{x}$ Landrace) and terminal boars of foreign selection). According to the results of the slaughter of 268 heads, the following indicators were obtained, which are shown in table 5 .

Table 5. Indicators of the lethal qualities of commercial hybrids.

\begin{tabular}{|l|c|c|c|c|c|}
\hline \multicolumn{1}{|c|}{ Indicators } & $\begin{array}{c}\text { Fat (6-7 } \\
\text { thoracic } \\
\text { vertebra). } \mathbf{~ m m ~}\end{array}$ & $\begin{array}{c}\text { Fat (10-11 } \\
\text { rib). mm }\end{array}$ & $\begin{array}{c}\text { Muscle depth. } \\
\text { mm }\end{array}$ & $\begin{array}{c}\text { Weight. } \\
\text { kg }\end{array}$ & $\begin{array}{c}\text { Output. } \\
\text { \% }\end{array}$ \\
\hline Average & 22.37 & 14.38 & 64.07 & 79.67 & 54.27 \\
\hline Standard error & 0.32 & 0.24 & 2.49 & 0.54 & 0.16 \\
\hline Median & 22 & 14.2 & 61.75 & 80.2 & 54.4 \\
\hline Fashion & 20 & 17.5 & 65.4 & 75.5 & 54.5 \\
\hline Standard deviation & 5.21 & 3.86 & 40.75 & 8.82 & 2.58 \\
\hline Excess & 0.58 & 0.15 & 243.22 & -0.09 & -0.23 \\
\hline Asymmetry & 0.26 & 0.40 & 15.23 & -0.02 & -0.40 \\
\hline Interval & 30 & 22.2 & 679.1 & 46 & 12.5 \\
\hline Minimum & 10 & 5.9 & 33.9 & 54.4 & 46.9 \\
\hline Maximum & 40 & 28.1 & 713 & 100.4 & 59.4 \\
\hline Reliability level (95.0\%) & 0.63 & 0.46 & 4.90 & 1.06 & 0.31 \\
\hline
\end{tabular}

It should be noted that there are higher levels of fat thickness at various points. The average thickness of the fat over the 6-7 thoracic vertebrae was $22.37 \mathrm{~mm}$, the thickness at the lumbar level was $14.38 \mathrm{~mm}$, the muscle depth was 64.07 , the weight was $79.67 \mathrm{~kg}$, the yield was $54.27 \%$. The degree of connection between the signs: the thickness of the fat over the 6-7 thoracic vertebrae and the meat yield has a negative value of 0.40 . A high negative value of -0.97 was noted between lumbar fat thickness and meat yield. The relationship between muscle depth and lean meat yield was 0.17 .

Table 6 shows the results of slaughter of 59 hybrids obtained from hybrid pigs and boars of the Pietrain breed of English selection.

Table 6. Indicators of the lethal qualities of hybrid gilts $(\mathrm{CBhL}) \mathrm{xP}$.

\begin{tabular}{|l|c|c|c|c|c|}
\hline \multicolumn{1}{|c|}{ Indicators } & $\begin{array}{c}\text { Fat (6-7 } \\
\text { thoracic } \\
\text { vertebra). } \\
\mathbf{m m}\end{array}$ & $\begin{array}{c}\text { Fat (10-11 } \\
\text { rib). mm }\end{array}$ & $\begin{array}{c}\text { Muscle } \\
\text { depth. mm }\end{array}$ & $\begin{array}{c}\text { Weight. } \\
\text { kg }\end{array}$ & $\begin{array}{c}\text { Output. } \\
\text { \% }\end{array}$ \\
\hline Average & 20.44 & 13.16 & 59.91 & 68.08 & 54.32 \\
\hline Standard error & 0.67 & 0.50 & 0.85 & 1.08 & 0.33 \\
\hline Median & 20 & 12.6 & 60.3 & 68 & 54.5 \\
\hline Fashion & 22 & 14.8 & 62.6 & 60.3 & 52.8 \\
\hline Standard deviation & 5.13 & 3.86 & 6.52 & 8.30 & 2.51 \\
\hline Excess & 1.21 & 1.86 & -0.23 & -0.48 & 1.79 \\
\hline Asymmetry & 0.60 & 0.97 & -0.08 & 0.17 & -0.98 \\
\hline Interval & 26 & 20.9 & 30.6 & 37.5 & 13.1 \\
\hline Minimum & 10 & 6 & 45.8 & 49.3 & 45.5 \\
\hline Maximum & 36 & 26.9 & 76.4 & 86.8 & 58.6 \\
\hline Reliability level (95.0\%) & 1.34 & 1.01 & 1.70 & 2.16 & 0.65 \\
\hline
\end{tabular}

The average indicators for the group of animals were: thickness of fat over 6-7 thoracic vertebrae $20.44 \mathrm{~mm}$, thickness at the lumbar level $13.16 \mathrm{~mm}$, muscle depth 59.91, weight $68.08 \mathrm{~kg}$, yield $54.32 \%$. The relationship between depth and meat yield is positive -0.32 .

A comparative analysis of the indicators of slaughter of purebred young animals and commercial hybrids obtained from various combinations of breeds is shown in Table 7. 
Tab. 7. Indicators of slaughter of purebred and hybrid young stock.

\begin{tabular}{|c|c|c|c|c|c|c|}
\hline \multirow{2}{*}{$\begin{array}{c}\text { Breed. } \\
\text { combination } \\
\text { of breeds }\end{array}$} & \multirow{2}{*}{$\begin{array}{c}\text { Amount } \\
\text { animals. } \\
\text { heads }\end{array}$} & \multicolumn{5}{|c|}{ Indicators } \\
\hline & & $\begin{array}{c}\text { Fat }(6-7 \\
\text { thoracic } \\
\text { vertebra }) . \\
\text { mm }\end{array}$ & $\begin{array}{l}\text { Fat (10-11 } \\
\text { rib). mm }\end{array}$ & $\begin{array}{c}\text { Muscle } \\
\text { depth. mm }\end{array}$ & $\begin{array}{c}\text { Weight. } \\
\text { kg }\end{array}$ & Output. $\%$ \\
\hline \multicolumn{7}{|c|}{ purebred young } \\
\hline KB (boars) & 60 & 17.3 & 11.75 & 57.25 & 77.16 & 55.82 \\
\hline KB (pigs) & 119 & 20.41 & 11.27 & 58.91 & 70.31 & 55.73 \\
\hline $\begin{array}{l}\text { Pietrain } \\
\text { (boars) }\end{array}$ & 38 & 15.68 & 8.87 & 66.67 & 75.71 & 57.87 \\
\hline Pietrain (pigs) & 91 & 18.70 & 9.52 & 63.22 & 76.59 & 57.02 \\
\hline \multicolumn{7}{|c|}{ two-breed hybrids } \\
\hline LDxLC & 22 & 20.45 & 11.10 & 61.85 & 77.29 & 56.36 \\
\hline LxKB & 339 & 22.23 & 14.48 & 56.24 & 73.45 & 53.72 \\
\hline $\mathrm{LxP}$ & 461 & 20.24 & 11.42 & 64.00 & 75.23 & 56.04 \\
\hline LxD & 159 & 22.78 & 13.26 & 61.18 & 79.02 & 54.97 \\
\hline $\mathrm{LxS}$ & 461 & 21.40 & 11.75 & 61.91 & 73.47 & 55.67 \\
\hline \multicolumn{7}{|c|}{ three-breed hybrids } \\
\hline$(\mathrm{KBxL}) \mathrm{xS}$ & 268 & 22.37 & 14.38 & 64.07 & 79.67 & 54.27 \\
\hline$(\mathrm{KB} \times \mathrm{L}) \times \mathrm{P}$ & 59 & 20.44 & 13.16 & 59.91 & 68.08 & 54.32 \\
\hline
\end{tabular}

Note: $K B$ - large white breed, $L$ - Landrace breed, LD - Landrace (Danish selection), LK - Landrace (Canadian selection), $P$ - Pietrain breed, $C$-terminal line boars (foreign selection).

High rates of meat yield of about 57\% were obtained for the breed of pietrain of English selection, there are high rates of muscle depth $63.22-66.67 \mathrm{~mm}$, category of carcasses is Eexcellent. Landrace breed hybrids: LDxLK - characterized by meat yield - 56.32\%, LxP $56.04 \%$ yield, LxD - 55\%, LxS - 56\%.

Gilts of the Large White breed showed good results: the thickness of the fat over the 6-7 thoracic vertebrae is $17.3-20.4 \mathrm{~mm}$, and the thickness of the fat on the lower back is 11.27-11.75 mm, the depth of the muscle is $57.25-58.91$. meat $70.31-77.16$. The presence of carcasses with a high category E (excellent) and category S - super over $60 \%$ of muscle tissue yield was noted. There is a good trend in the category of meat. The range of variation allows breeding to increase this indicator.

One of the most reliable ways to change and manage pork quality is through breeding. The theoretical prerequisite for breeding to increase meat content and improve the quality of pork is a high heredity of traits. Meat color (0.71), water-holding capacity (0.59), tryptophan content $(0.58)$ and muscle fiber area $(0.54)$ are inherited to a high degree, fat content is somewhat worse.

Analyzed meat samples of purebred gilts and commercial hybrids obtained from various breed combinations, the results are shown in table 8 .

Pedigree hybrids: variants - $\mathrm{F} 1 \mathrm{x}(\mathrm{KBxP})$ direct and $\mathrm{F} 1 \mathrm{x}(\mathrm{PxKB})$ reverse, the genotype contains $25 \%$ - landrace, $50 \%$ - large white, 25\% - pietrain; variant - F1x(DxP) straight, genotype contains $25 \%$ - landrace, $25 \%$ - large white, $25 \%$ - duroc, $25 \%$ - pietrain. Hybrids of the breed combination F1xD, the genotype contains $25 \%$ - landrace, $25 \%$ - large white, $50 \%$ - duroc.

Technological properties depend on the moisture-retaining characteristics of the meat. A high $\mathrm{pH}$ value increases the water-holding properties of meat. Good quality meat has a water holding capacity of 53-66\%.

The presence of dyes in meat (90\% myoglobin and $10 \%$ hemoglobin) mainly determines the color of the meat. The intensity of the color of meat is influenced by the breed, sex, age, the way of feeding the animals, as well as the conditions and duration of storage and the processes of its maturation. The color of the meat depends to a certain extent on the $\mathrm{pH}$. Pork at $\mathrm{pH} 5.6$ has a pink-red color, and at $\mathrm{pH} 6.5$ and above it is darker. The pink-red color of the pork corresponds to good bleeding of carcasses and fresh meat. 
Table 8. Qualitative indicators of meat of purebred gilts and commercial hybrids.

\begin{tabular}{|c|c|c|c|c|c|c|c|}
\hline marbling & color & $\begin{array}{l}\text { color } \\
\text { intensity. } \\
\text { food }\end{array}$ & $\mathrm{pH}$ & $\begin{array}{l}\text { moisture } \\
\text { binding } \\
\text { capacity }\end{array}$ & $\begin{array}{c}\text { moistur } \\
\text { e. } \%\end{array}$ & fat. $\%$ & ash. $\%$ \\
\hline \multicolumn{8}{|c|}{ Danish Landrace x Canadian Landrace } \\
\hline 3.65 & 2.6 & 49.5 & 5.65 & 58.42 & 75.10 & 1.79 & 1.08 \\
\hline \multicolumn{8}{|c|}{ Landrace Danish } \\
\hline 2.6 & - & 24.0 & 5.80 & 59.31 & 75.36 & 0.58 & 2.14 \\
\hline \multicolumn{8}{|c|}{ Landrace Canadian } \\
\hline 3.8 & - & 16.6 & 5.84 & 55.61 & 74.17 & 1.52 & 1.30 \\
\hline \multicolumn{8}{|c|}{ Landrace and Pietrain } \\
\hline 4.1 & 2.6 & 68.1 & 5.54 & 56.77 & 74.69 & 1.61 & 0.84 \\
\hline \multicolumn{8}{|c|}{ Landrace x KB (England) } \\
\hline 3.4 & 3.0 & 40.4 & 5.57 & 55.20 & 74.95 & 1.10 & 0.85 \\
\hline \multicolumn{8}{|c|}{ Landrace x KB (England) } \\
\hline 3.0 & 2.4 & 22.5 & 5.70 & 59.55 & 74.85 & 1.14 & 1.95 \\
\hline \multicolumn{8}{|c|}{$\mathrm{F} 1 \mathrm{x}(\mathrm{KBxP})$} \\
\hline 2.9 & 3.7 & 80.86 & 5.66 & 57.78 & 74.56 & 1.31 & 1.21 \\
\hline \multicolumn{8}{|c|}{$\mathrm{F} 1 \mathrm{x}(\mathrm{PxKB})$} \\
\hline 2.6 & 2.95 & 80.27 & 5.59 & 55.51 & 74.81 & 1.25 & 1.16 \\
\hline \multicolumn{8}{|c|}{$\mathrm{F} 1 \mathrm{x}(\mathrm{DxP})$} \\
\hline 2.4 & 2.8 & 79.87 & 5.616 & 56.21 & 74.83 & 1.52 & 1.30 \\
\hline \multicolumn{8}{|c|}{ F1xD } \\
\hline 3.2 & 2.6 & 80 & 5.70 & 55.3 & 74.66 & 1.91 & 1.13 \\
\hline \multicolumn{8}{|c|}{ KB (Jubilee) } \\
\hline 2.8 & 2.4 & 82 & 5.68 & 59.21 & 74.98 & 0.90 & 1.22 \\
\hline \multicolumn{8}{|c|}{ L (Jubilee) } \\
\hline 3.07 & 3 & 81.87 & 5.54 & 57.09 & 74.58 & 1.35 & 1.24 \\
\hline \multicolumn{8}{|c|}{ D (Jubilee) } \\
\hline 3.6 & 3 & 74.59 & 5.71 & 57.18 & 73.52 & 1.92 & 1.17 \\
\hline \multicolumn{8}{|c|}{$\mathrm{P}$ (Jubilee) } \\
\hline 3 & 3 & 83.8 & 5.34 & 57.96 & 75.04 & 0.95 & 1.13 \\
\hline
\end{tabular}

The color of the meat is determined visually by standards, has a positive effect on the visual appeal of the meat, that is, its presentation. The color index of 3.7 points was noted in samples of commercial hybrids F1x (KBhP), in samples of purebred Landrace, Duroc, Pietrain - 3.Figure 1 shows meat color standards.

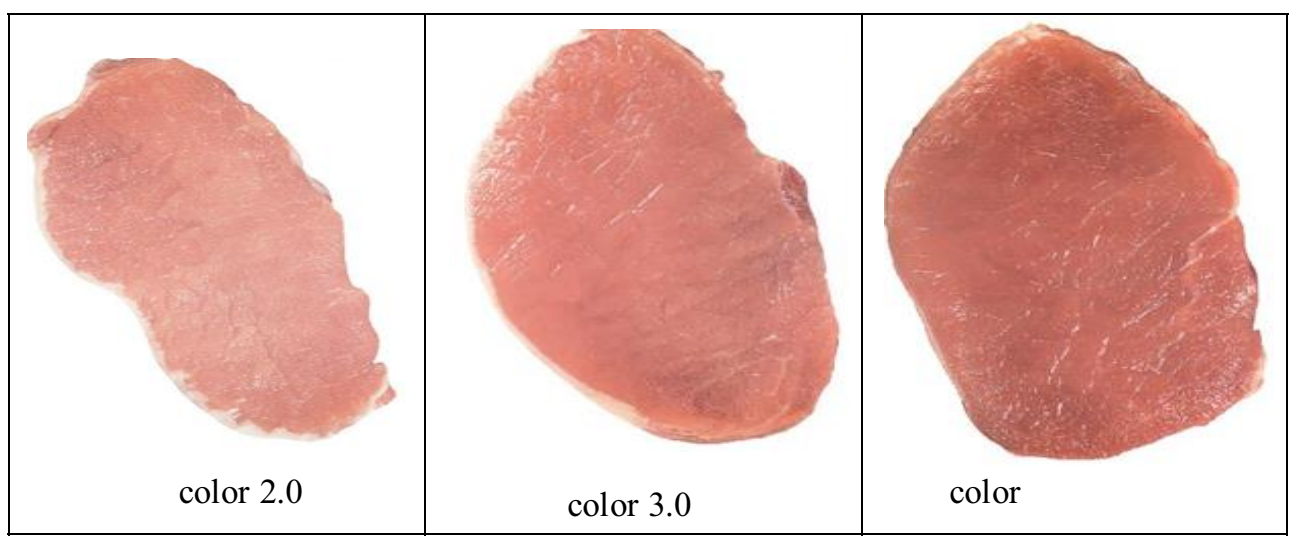

Fig. 1. Standards for the determination of meat color.

Marbling is characterized by fat content in the muscles, around or between muscle fibers. Marbling is determined visually. When comparing meat samples, it was noted that the 
marbling index in purebred duroc gilts was 3.6 points, three-breed hybrids $25 \%$ landrace, $25 \%$ large white, $50 \%$ duroc - 3.2, purebred landrace - 3.07, purebred pietrain 3.0, commercial hybrids F1x(KBxP) - 2.9. Most of the meat samples were characterized by the marbling index -3 points. Significant fluctuations of individual values from the average are observed in samples of the Duroc breed, the sigma was 0.97. Figure 2 shows the marbling standards of meat.

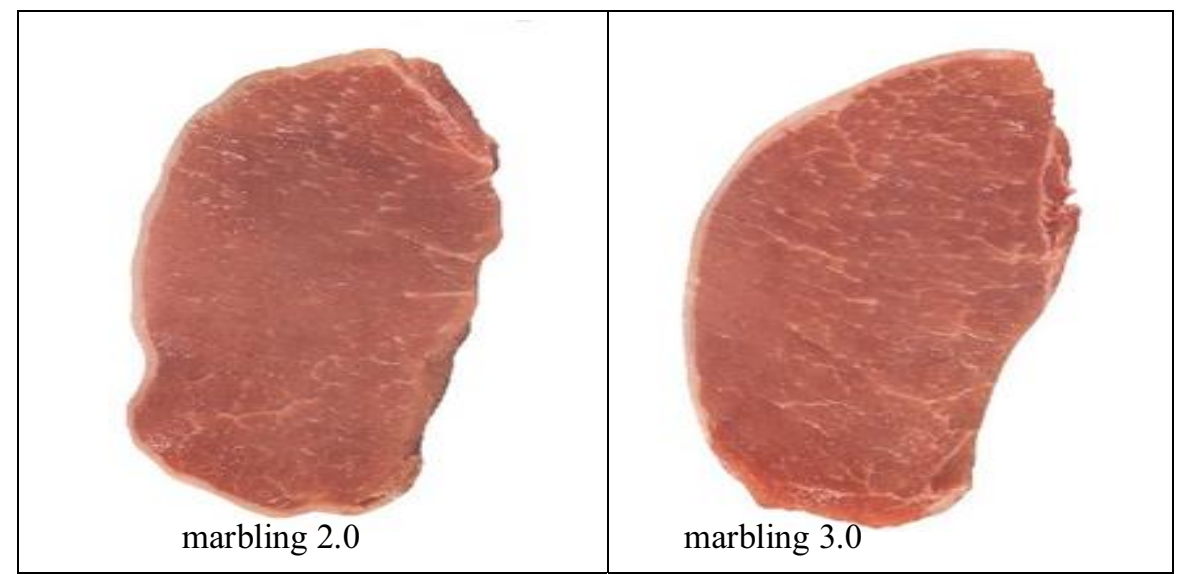

Figure 2. Standards for determining the marbling of meat.

Intramuscular fat is associated with softness, juiciness, and palatability. The marbling index affects the external attractiveness of meat, but its contribution to the general quality of meat is rather small. Correlations with the protein content have a different direction from negative $-0.22-0.56$ to positive $0.04-0.70$. [1,3,6]

Chemical analysis of meat samples is shown in Fig. 3.

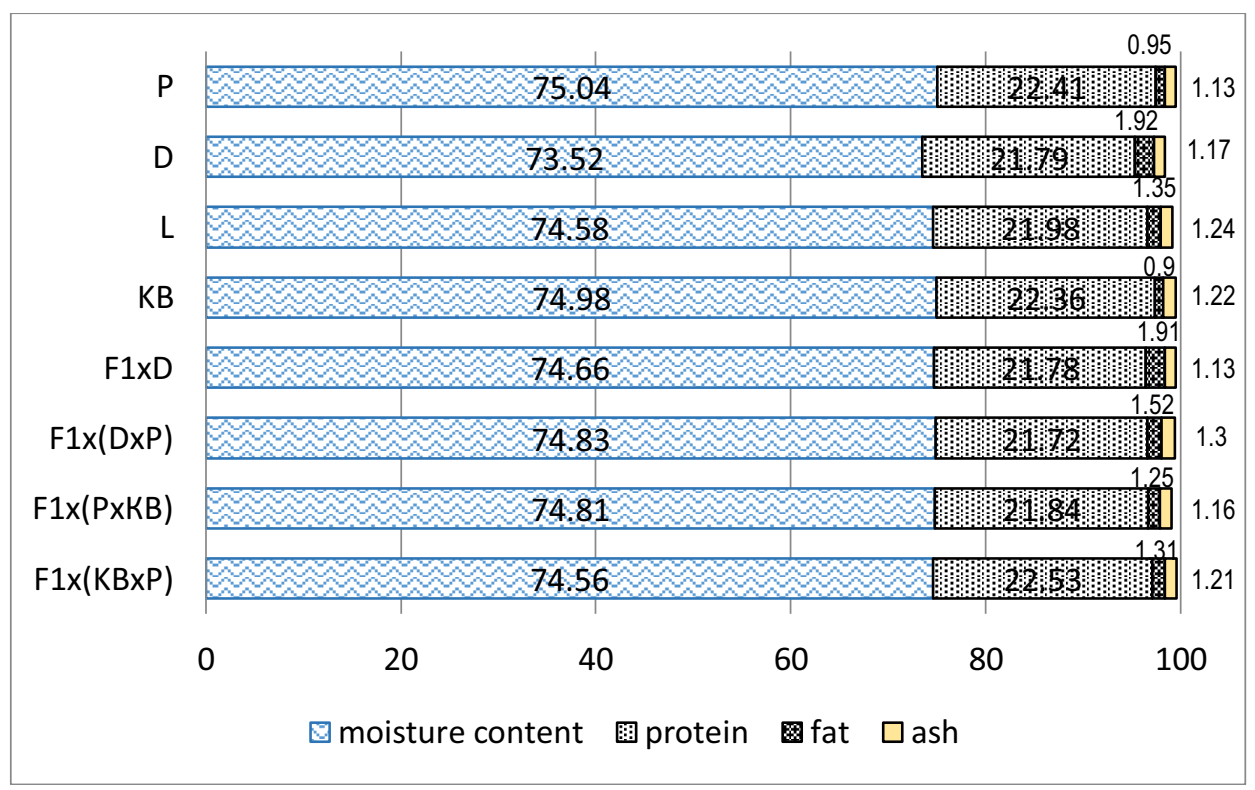

Fig. 3. The chemical composition of purebred meat and hybrid pigs. 
Moisture content from $73.52 \%$ to $75 \%$, protein - from 21.7 to $22.53 \%$, fat - from 0.95 to $1.92 \%$, ash - 1.13-1.24. The lowest moisture content is observed in gilts of the Duroc breed - 73.52\%, Landrace - 74.58, F1x hybrids (KBxP) - 74.56\%. The highest moisture content is observed in pigs of the Pietrain breed $-75.04 \%$, in the large white breed -74.98 . The results of our research coincide with the data obtained by O.V. Grishanova [2] noted that no significant differences were found in the moisture content in meat of $72.49-73.91 \%$. The smallest value was noted in three-breed hybrids (KBxBM)xD - 72.49\%.

The histogram characterizes the protein content of $22.53 \%$ observed in samples obtained from four breed hybrids $\mathrm{F} 1 \mathrm{x}(\mathrm{KBxP})$, pietrain $-22.41 \%$, large white $-22.36 \%$. The lowest fat content was noted in samples of large white breed $-0.9 \%$, the highest in samples of Duroc - 1.92\%, F1xD hybrids - 1.91\%, F1x(DxP) - 1.52\%.

Many researchers have found that the level of intramuscular fat practically does not depend on the thickness of the back fat. $[3,4,5]$

According to the literature, the influence of the breed on the quality of pork is noted. So, O.V. Grishanova observed differences in the content of muscle tissue in the carcass - 59.0$61.6 \%$ in pigs of various types (Poltava, Kemerovo meat types), 52.5-53.5\% (Ukrainian steppe white, large black breed), fat thickness respectively - 29-32 $\mathrm{mm}$ and 35-41 $\mathrm{mm}$. [2]

\section{Conclusion}

Summarizing the information received, it is possible to note the rather high rates of meat yield for purebred and commercial animals, which allows us to trace the tendency to improve the quality indicators of meat, depending on the crossbreeding program of various breeds.

Analysis of the growth and development of young animals showed high early maturity and fattening qualities in Landrace pigs: 146 days, body length $-121 \mathrm{~cm}$, average daily gain - $885 \mathrm{~g}$, muscle depth - $56 \mathrm{~mm}$, meat yield - 59\%; in pigs of large white breed, the age of reaching a live weight of $100 \mathrm{~kg}$ was 163 days, an average daily gain of $810 \mathrm{~g}$, body length - $120 \mathrm{~cm}$, muscle depth - $57 \mathrm{~mm}$, meat yield - 58\%; F1 hybrid maternal gilts have early maturity - 154 days, body length $-120 \mathrm{~cm}$, average daily gain $-879 \mathrm{~g}$, muscle depth - 55 $\mathrm{mm}$, meat yield $-55 \%$.

Analysis of slaughter indicators for commercial hybrids over a nine-year period revealed a decrease in live weight of hybrids by $9.7 \mathrm{~kg}$, which affected a decrease in carcass weight by $7.6 \mathrm{~kg}$, fat thickness by $6.8 \mathrm{~mm}$. The largest number of carcasses weighed from $68.2 \mathrm{~kg}$ to $85.8 \mathrm{~kg}$. The most common carcass weight is $77.5 \mathrm{~kg}$. The average muscle depth was $60.4 \mathrm{~mm}$; the presence of hybrids with a high muscle depth of up to $69 \mathrm{~mm}$ was noted. The most common muscle depth is $59.5 \mathrm{~mm}$. The average percentage of meat yield was $54.4 \%$, there are fluctuations from 32.3 to $61 \%$ of meat yield, the limit of variability is $28.7 \%$. The largest number of animals had a percentage of meat yield within $54 \%$. Positive correlations were revealed, confirming that with an increase in the weight of carcasses, the thickness of the fat and the depth of the muscle increase, with an increase in the depth of the muscle, the yield of meat tissue increases. Negative correlations indicate that with an increase in fat thickness of $100 \mathrm{~kg}$, the percentage of meat tissue yield and muscle depth will decrease.

An analysis of the comparison of meat samples revealed that the best marbling index was noted in gilts of the Duroc breed 3.6 points, in hybrids (25\% Landrace, $25 \%$ Large white, 50\% Duroc) - 3.2, purebred Landrace - 3.07, purebred pietrain 3.0, commercial hybrids F1x (KBhP) - 2.9. The color of the meat and the marbling have a positive effect on the visual appeal, that is, the presentation. A color index of 3.7 points was noted in samples of commercial hybrids F1x(KBxP), in samples of purebred Landrace, Duroc, Pietrain - 3. Correlation relations of color with protein content have a different direction from negative - 
0.03-0.16 to positive $0,07-0.65$, this is due to breed characteristics. In the analyzed samples, the color intensity is significantly higher than 65 units. This testifies to the very good quality of the meat. It was found that the relationship between color intensity and protein content has a different direction from negative $-0.22-0.56$ to positive $0.04-0.70$ in different variants of crossing.

Recently, in determining the quality of meat, more and more attention is paid to the issue of moisture capacity. In purebred gilts and commercial hybrids, large white $-59.21 \%$, pietrain - 57.96\%, F1x(KBxP) - 57.78\%, duroc - 57.18\% stand out, other hybrids and purebreds from $55.3 \%$ to $57,01 \%$.

According to the chemical composition of meat, a protein content of $22.53 \%$ is noted in samples obtained from four breed hybrids $\mathrm{F} 1 \mathrm{x}(\mathrm{KBxP})$, pietrain $-22.41 \%$, large white $22.36 \%$. The lowest fat content was noted in samples of large white breed $-0.9 \%$, the highest in samples of Duroc - 1.92\%, F1xD hybrids - 1.91\%, F1x(DxP) - 1.52\%.

Thus, the assessment of meat qualities and the established relationships between the traits allow selection and selection of animals in the desired direction.

\section{References}

1. O.L. Tretyakova, Polythematic network electronic scientific journal of the Kuban State Agrarian University, 134, 514-524 (2017)

2. M.S. Brar, Journal of General Virology, 96(7),1570-1580 (2015)

3. Engblom Animal Industry report. Iowa State Universite, 56, 86-89 (2010)

4. I.S. Frydas, Vet. Res, 44, 132-134 (2013)

5. Haimi-Hakala, Porcine Health Manag, 23, 19 ( 2017)

6. A.M. Jamieson, Science, 340, 1230-1234 (2013)

7. K. Han, Clinical and vaccine immunology, 10, 1600-1607 (2011)

8. S.H. Kim, Veterinary Microbiology, 143, 394-400 (2010)

9. B. Close, Animal Husbandry of Russia, 10, 29-30( 2014)

10. J.H. Lee, Asian-Australasian Journal of Animal Science, 28(10), 13881393 (2015)

11. D. Lucac, African Journal of Agricultural Researchvol, 8 (37), 46644669 (2013)

12. C. Leng, Vet Immunol Immunopathol, 15, 65-71 (2014)

13. J.K. Liu, Transbound Emerg Dis, 64(6), 2059-2074 (2017)

14. D. Radojkovic, Belgrade-Zeman: Biotechnology in Animal Husbandry. Institute for Animal Husbandry, 27(3), 777-783 (2011)

15. L. Zhang, PLoS One, 11(5), 1542 (2016) 